\title{
Arctic ecosystems - relations between cyanobacterial assemblages and vegetation (Spitsbergen)
}

\author{
Miroslawa Pietryka ${ }^{1 *}$, Dorota Richter ${ }^{1}$, Jan Matula ${ }^{2}$ \\ Wrocław University of Environmental and Life Sciences, \\ ${ }^{1}$ Department of Botany and Plant Ecology, pl. Grunwaldzki 24a, PL 50-363 Wrocław, Poland, \\ "e-mail: miroslawa.pietryka@upwr.edu.pl, \\ ${ }^{2}$ Institute of Biology, Kożuchowska 5B St, 51-631 Wrocław, Poland,
}

Received: 20 September 2017 / Accepted: 30 November 2017

\begin{abstract}
The paper describes cyanobacterial assemblages in relation to mosses and vascular plants forming mosaic communities in Arctic tundra. The study area is located in the north of the Hornsund fjord. In the selected 14 type of habitats, the study analyzed the quantitative and qualitative share of cyanobacteria, mosses and vascular plants. Due to their similarity in cyanobacterial assemblages and their relations to vegetation, they were divided into 10 groups. Each group was characterized by a particular combination of species with a distinguishing cyanobacteria dominant species and mosses and vascular plants. The significant role of cyanobacteria crusts and mats in the formation of the Spitsbergen tundra suggests they should be included in the descriptions of communities present in the region.
\end{abstract}

Key words: ecology of cyanobacteria, Svalbard's vascular plants and mosses, blue-green algae, Hornsund.

\section{Introduction}

In the vast terrains of the Arctic severe climatic conditions and specific habitat conditions determine the processes of colonization and succession of vegetation, especially on particularly on initial grounds, on surfaces uncovered as a result of the recession of the glaciers. These areas are characterized by low amounts of nutrients, especially nitrogen and phosphorus, which inhibits and narrows the vegetation. In such conditions biological crusts of cyanobacteria microalgae, mosses and lichens are most successful and play a dominant role in the majority of polar ecosystems (Elvebakk, 1994; Kanda \& Inoue, 1994; Turetsky et al., 2012). The characteristic crusts and mats are built of cyanobacteria and are often responsible for the whole production of biomass in the area (Dickson, 2000; Hu \& Liu, 2003; Elster \& Benson, 2004; Kaštovská et al., 2005; Thomas et al., 2008; Pócs, 2009). Ecophysiological characteristics of cyanobacteria include the ability to grow in a large spectrum of temperatures, a tolerance to desiccation, freezing and salinity stress, and adaptive strategies to high levels of solar radiation. These features contribute to their success and dominance in regions lacking other vegetation (Warwick, 2002). By stabilizing soil surfaces and providing nutrients they prepare the habitat for further stages of growth. Such surfaces are gradually inhabited by dominant mosses and lichens and a few vascular plants.

The superiority of mosses in extreme habitats is a result of their associations with epiphytic cyanobacteria. Associations between bryophytes and cyanobacteria have been a subject of research for a long time (Solheim \& Zielke, 2002; Zielke et al., 2002; Lindo et. al., 2013; Zhang et. al., 2014). The mutualistic relations between the organisms are the benefits resulting from cyanobacteria ability to nitrogen fixation. It is particularly important in environments lacking in nutrients (especially in polar regions), where nitro- 
gen shortages result in lasting associations between these organisms. In such a case the bryophyte receives nitrogen from the cyanobacteria, providing carbohydrates, shelter and protection in return (Steinberg \& Meeks, 1991; Rai et al., 2000; Turetsky, 2003; Gavazov et al., 2010; Rousk et al., 2013). Research conducted in the Arctic and the Antarctic has shown that nitrogen fixing through cyanobacteria and mosses associations constitutes a significant part of nitrogen export in terrestrial polar ecosystems (Chapin \& Bledsoe, 1992; Steward et al., 2011).

Despite detailed studies regarding the roles of cyanobacterial crusts and associations between cyanobacteria and mosses, so far the relation between cyanobacteria assemblages and mosses and vascular plants has not been studied. Many years phytosociological research conducted in Spitsbergen only studied mosses and vascular plants (Dubiel \& Olech, 1990; Olech, 1990, 2008; Cooper et al., 2004; Elvebakk, 2005; Cooper, 2011). Studies of cyanobacteria, on the other hand, were mostly focused on the biodiversity of phycoflora (Thomasson, 1958, 1961; Willen, 1980; Matuła, 1982; Plichta \& Luścińska, 1988; Oleksowicz \& Luścińska, 1992; Skulberg, 1996; Turicchia et al., 2005; Matuła et al., 2007; Kim et al., 2008, 2011; Richter et al., 2009; Komárek et al., 2012; Davydov, 2013, 2014, 2016, 2017; Raabová et al., 2016; Davydov \& Patova, 2017) or on the morphological and ecological characteristics of individual species (Strunecký et al., 2012; Richter \& Matuła, 2013; Richter et al., 2014a; Kvíderová et al., 2011; Komárek \& Kovacik, 2013). Only recently have there been whole some studies of habitats, where cyanobacteria, algae, lichens, mosses and vascular plants are equal components of tundra habitats (Richter et al., 2014b, 2015). Because the important role of cyanobacteria and algae in the formation of Spitsbergen community tundra should they find out in the description of plant communities. This study is focused on the summary of research into the interdependence between assemblages cyanobacteria and vegetation of the tundra in the Hornsund fjord.

\section{Study area}

The study area is located in the Hornsund fjord of West Spitsbergen. Hornsund fjord is spread in a latitudinal way, and from is from both sides approached by meridional mountain ranges. Studies have been conducted for several years near the Polish Polar Station, north of the Hornsund fjord, in the area covering the Revdalen valley with the Revelva River, the plain of raised marine terrace Fuglebergsletta and Gnalodden, Fuglebekken catchment, as well as the Ariekammen, Fugleberget and Gnalberget slopes.

The following study is a summary of years of research carried out during the Arctic summer in July and August in the years 2011-2013. It presents research results from
14 habitat types, differing in moisture, trophy and existing communities of mosses and vascular plants. A detailed characteristics and location of particular habitats is presented in Figure 1 and Table 1.

\section{Material and methods}

Sample material was collected from the surface of soil and mosses. 14 ecologically different habitats were selected for the studies and 5 representative samples were collected from each. 70 samples were analyzed in total.

In the field, habitats were studied for percentage coverage of cyanobacteria thalli, mats and crusts. Microscopically, the quantitative of particular species was estimated on scale of 1-5, were 1 means sporadic occurrence and 5 means dominant species.

Species observations were conducted with a digital microscope Nikon Eclipse TE2000-S light. The taxa were digitally archived using the NIS image analysis program, which enables saving the images with a proper scale of objects. The identification was performed live and also on material preserved. Cyanobacteria were identified according to the following monographs: Komárek and Anagnostidis (1999, 2005), Komárek (2013), Strunecky et al. 2013.

\section{Results}

Cyanobacteria in relation to habitats types (Table 1)

The initial stage of cyanobacteria-moss habitat (IS) and surface of polygonal soil (PS) and cyanobacteria-moss snowbed (SB), (Fig. 2) are covered mainly by Anthelia juratzkana, Sanionia uncinata, Saxifraga oppositifolia and $S$. cespitosa. Among the mentioned mosses and vascular plants, on the surface there are also dirty-gray, elastic cyanobacterial crusts built of the aerophytic form of Schizothrix cf. lacustris. Among them the study also recorded brown thalli formed by Petalonema crustaceum, Tolypothrix tenuis, Microcoleus vaginatus, Stigonema cf. mamillosum, Calothrix cf. parietina and Saccoconema sp. Within crusts built of the Schizothrix cf. lacustris (aerophytic form) there are also numerous other species: Gloeocapsa biformis, G. punctata and Chroococcus turgidus. Among cyanobacterial crusts the study also observed large quantities of free-living, spherical olive-green colonies of Nostoc commune and less numerous accompanying $N$. cf. paludosum.

Habitats with the dominance of cyanobacterial crusts (wet cyanobacterial crust (WC) and cyanobacterial crust (CC)) with a large proportion of Sanionia uncinata were characterized by the greatest variety of cyanobacteria, especially with respect to heterocytous and coccoid types. On such terrain, there was a dominance of macroscopic, 
spherical or spread, olive-green colonies of Nostoc commune and cyanobacterial crusts. Thalli of Nostoc commune covered up to $50 \%$ of uncovered, moist soil in the analyzed habitats. Elastic and gray cyanobacterial crusts were formed of the subaerophytic form of Schizothrix cf. lacustris with Petalonema crustaceum, Tolypothrix tenuis and Microcoleus vaginatus. Within them there were also small colonies of Symplocastrum sp., and, in large quantities, coccoid species: Gloeocapsa punctata, G. biformis, Chroococcus turgidus.

Oligotrophic flow water habitat (FW) with Barbula sp. (dominant) and other mosses was characterized by the presence of cyanobacterial crust, which, in shape of dirty greenish, hard thalli, covered branches and leaves of mosses and the long cell form of Nostoc commune in the form of vast, lobular, olive thalli. Cyanobacterial crusts formed mostly of the plankton form of Schizothrix cf. lacustris, Petalonema crustaceum, Microcoleus vaginatus, Symplocastrum $\mathrm{sp}$. In the crusts the study recorded many coccoid species, such as Gloeocapsa kuetzingiana, G. punctata,
Aphanothece clathrata, A. caldariorum, the aerotope form of Woronichinia sp., the granular form of Gloeothece sp. and the dark mucilaginous form of Aphanocapsa sp.

In oligo-mesotrophic moss habitat (OM) and wet oligotrophic moss habitat (WO) covered with a mosaic of mosses (Sanionia uncinata, Straminergon stramineum, Warnstorfia exannulata, Bryum pseudotriquetrum) on the branches and leaves of mosses and between them there were dirty green and gray cyanobacteria crusts formed of granular form of Leptolyngbya sp. (dominant) and Petalonema crustaceum, Microcoleus vaginatus, Gloeocapsa punctata and G. tornensis. The studied habitates are also characterized by a large proportion of Nostoc commune (Fig. 3) and N. cf. punctiforme which formed macroscopic leathery lobes of olive-green thallus on soil surface and between mosses. Oscillatoria cf. ornata was characteristic for these habitats.

Wet oligotrophic cyanobacterial crust with Saxifraga spp. (OS), (Fig. 4) covered with a Saxifraga oppositifolia community with $S$. cespitosa, Salix polaris was domi-

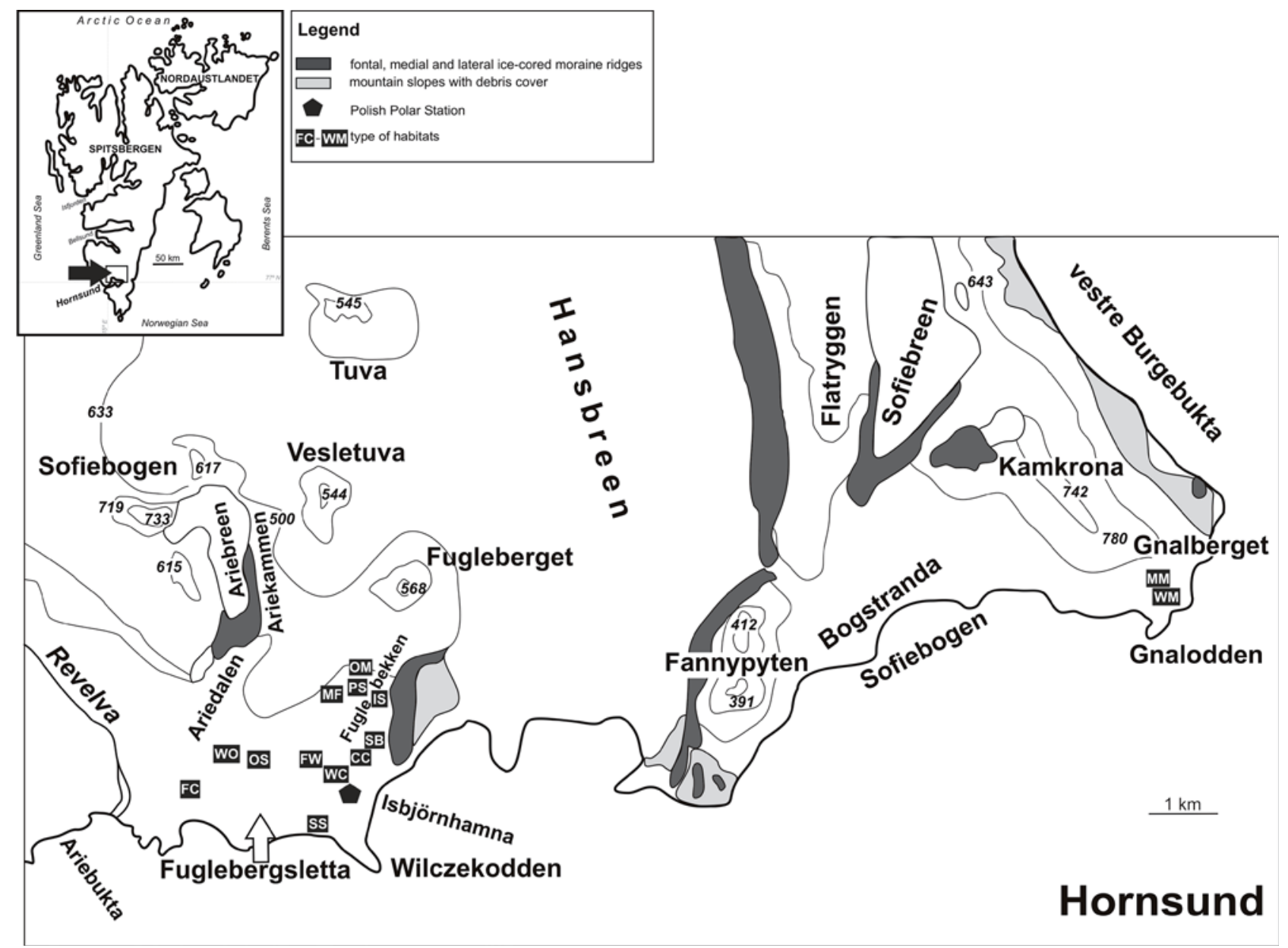

Figure 1. Location of the Svalbard, Spitsbergen - Hornsund fjord (Fuglebekken catchment, Fuglebergsletta marine terrace and Gnalberget slope, Gnolodden plain terrace) 







\begin{tabular}{|c|c|c|c|c|c|}
\hline 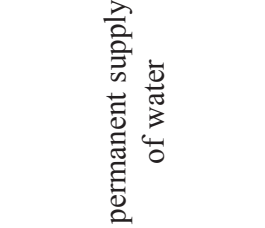 & 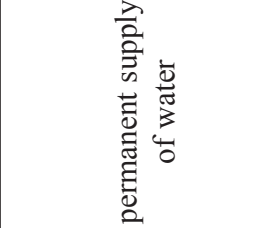 & $\begin{array}{l}\text { ఫ్ञ } \\
\text { चु }\end{array}$ & 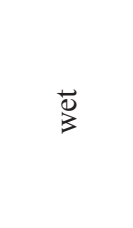 & $\stackrel{\overrightarrow{0}}{3}$ & 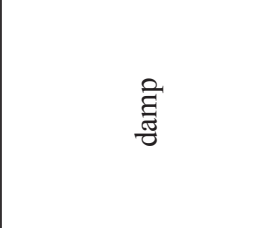 \\
\hline 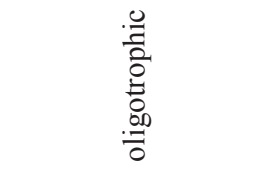 & 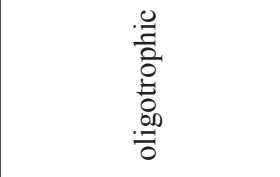 & 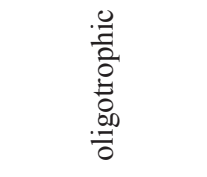 & 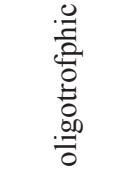 & 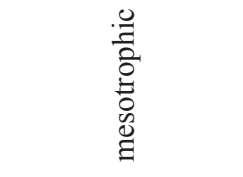 & 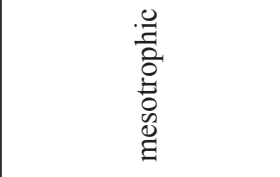 \\
\hline 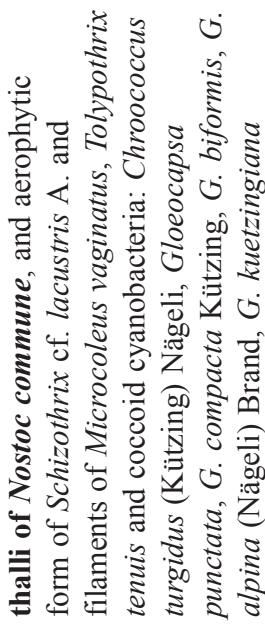 & 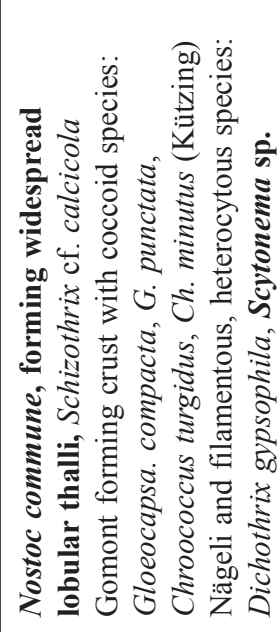 & 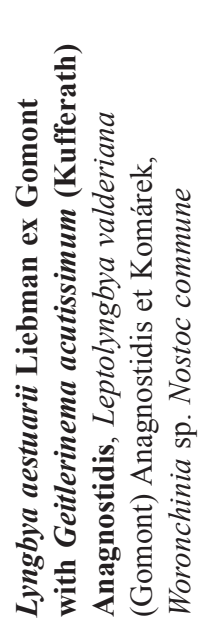 & 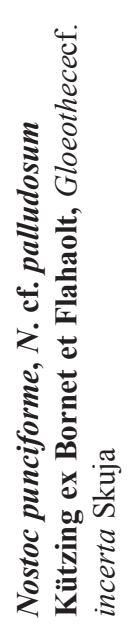 & 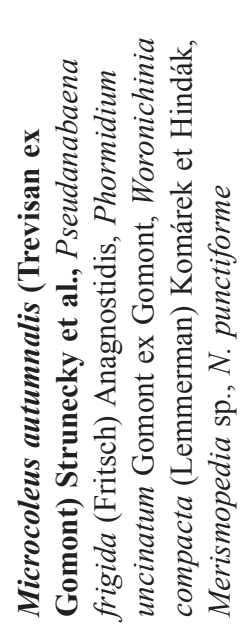 & 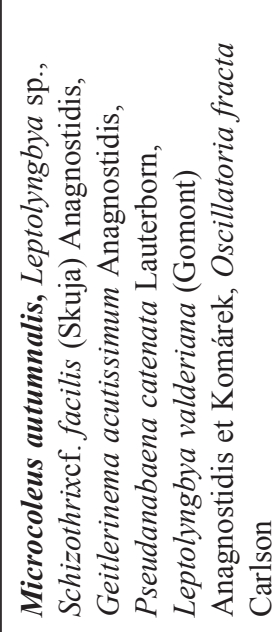 \\
\hline 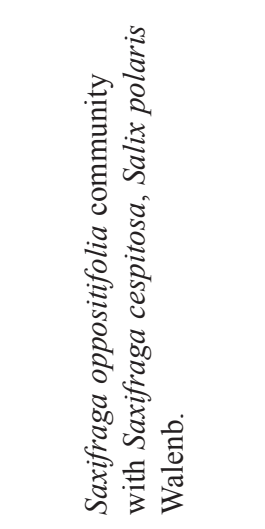 & 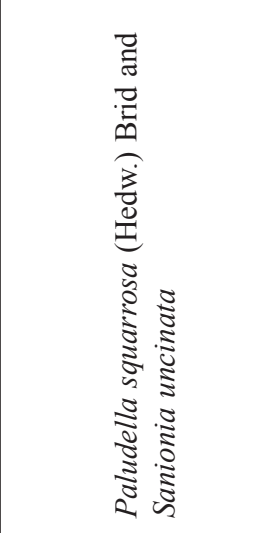 & 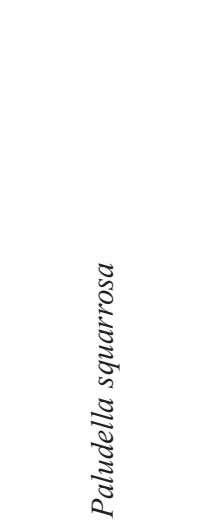 & 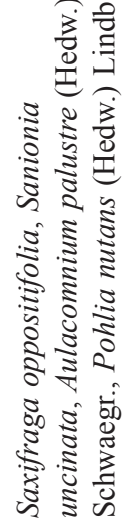 & 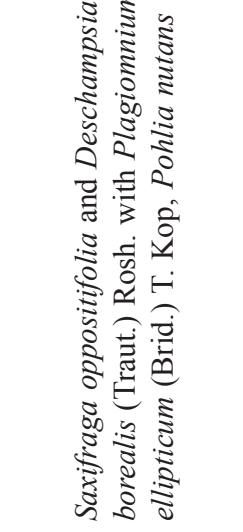 & 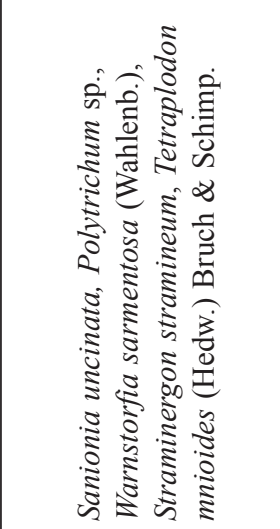 \\
\hline ? & i & $\tilde{n}$ & $\sum_{3}$ & $\sum$ & $\Sigma$ \\
\hline 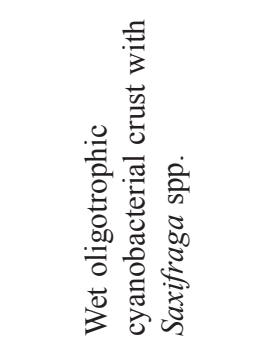 & 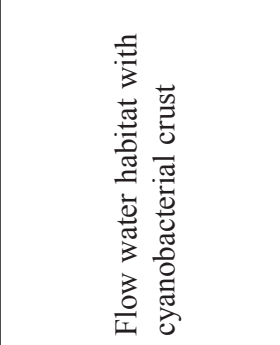 & 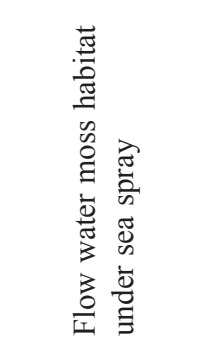 & 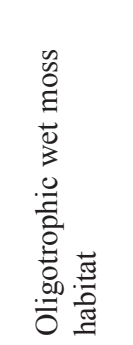 & 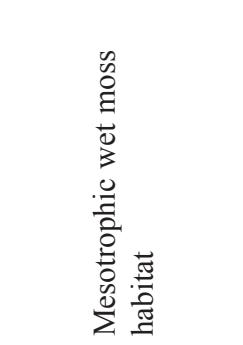 & 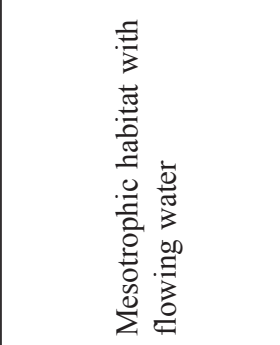 \\
\hline
\end{tabular}



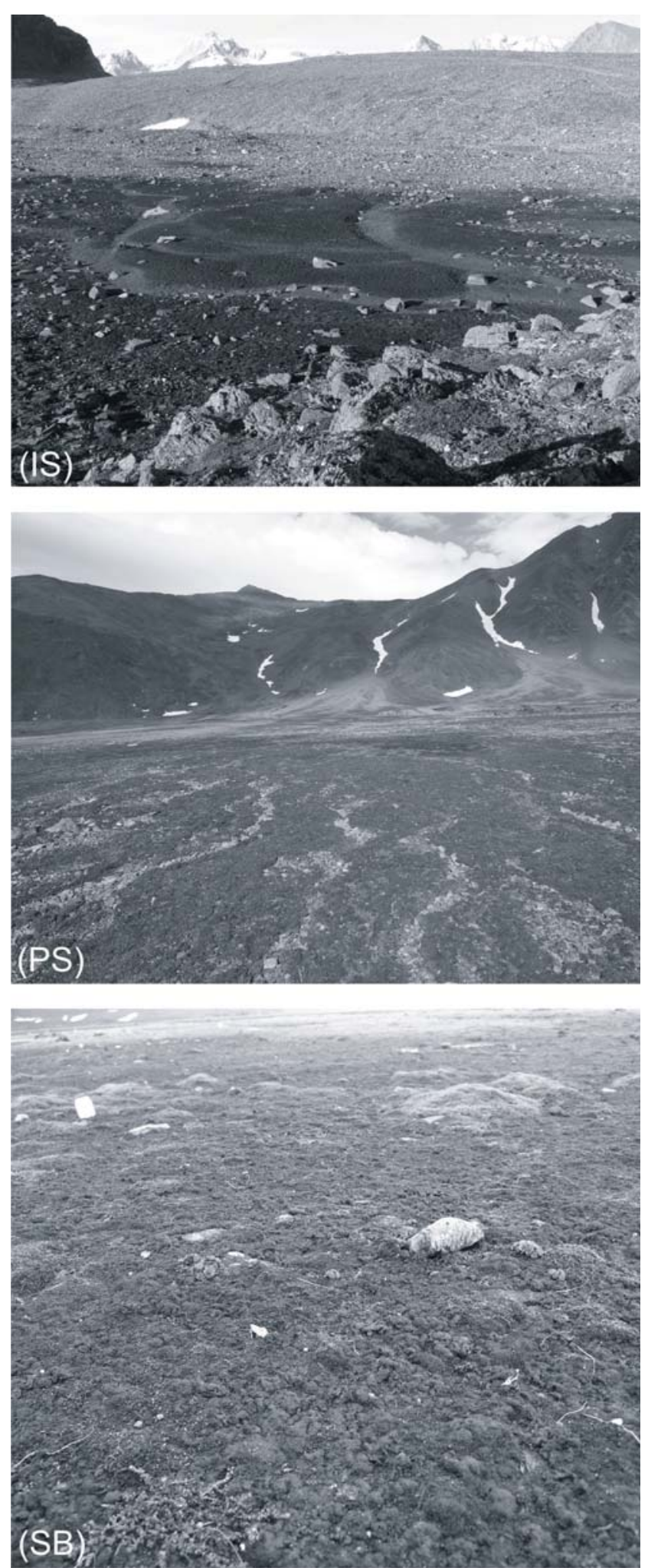

Figure 2. View of the initial stage of cyanobacteria-moss habitat (IS), polygonal soil (PS) and cyanobacteria-moss snowbed (SB) nated by the thallus of Nostoc commune. It formed a vast, leathery thallus on the surface. The sub-dominant species was cyanobacterial soil crust formed of elastic, dirty-gray filaments of the aerophytic form of Schizothrix cf. lacustris and filaments of Microcoleus vaginatus, Tolypothrix tenuis and numerous coccoid cyanobacteria: Chroococcus turgidus, Gloeocapsa punctata, G. compacta, G. biformis, G. alpine, G. kuetzingiana.

Flow water habitat with cyanobacterial crust (FC) with a large share Palludella squarosa and Sanionia uncinata was characterized by the dominance of Nostoc commune forming widespread lobular thalli covering up to $50 \%$ of the tundra surface. At the bottom of the flows the study recorded white, gray and green from the bottom cyanobacterial crusts formed of Schizothrix cf. calcicola. In the upper parts of the mats there were numerous nodular brown and orange thalli of Dichothrix gypsophila and long, dark olive and black filaments of Scytonema sp. (brown sheath).

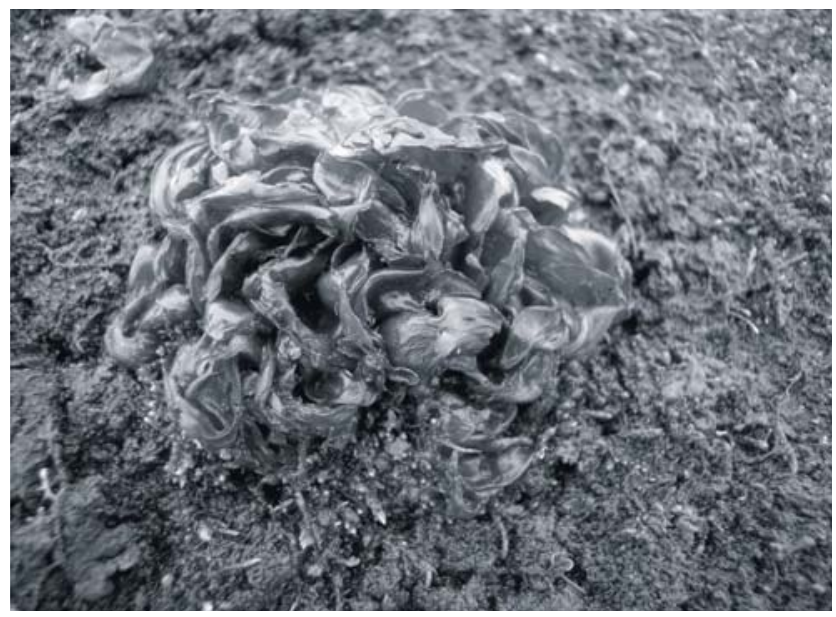

Figure 3. Macroscopic view of Nostoc commune thallus

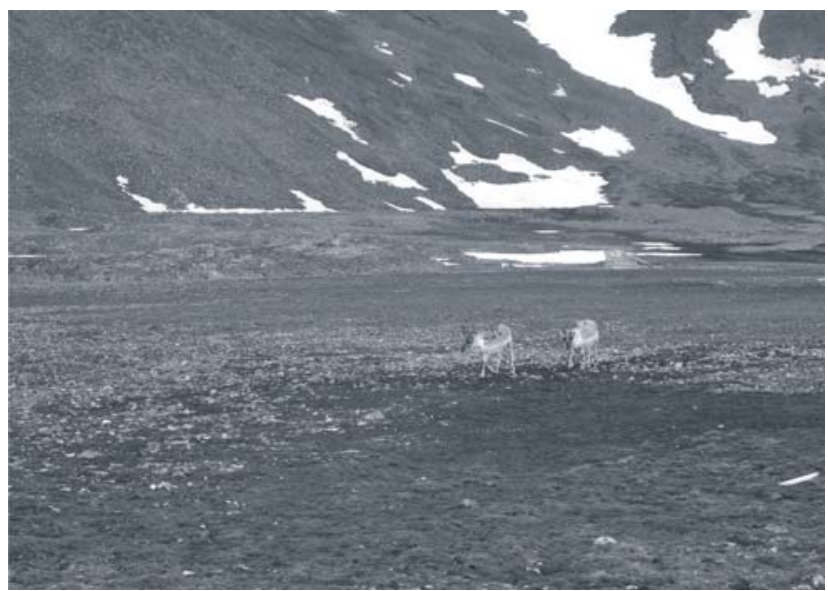

Figure 4. View of the wet oligotrophic cyanobacterial crust with Saxifraga spp. (OS) 
This species was characteristic for this habitat and didn't occur in any other studied tundra. Among the filaments of Sch. calcicola the study recorded coccoid species Gloeocapsa compacta, G. punctata, Chroococcus turgidus, Ch. minutus.

In the broad stream flowing through the oligotrophic moss habitat with Palludella squarosa (flow water habitat with cyanobacterial crust-SS) Lyngbya aestuarii was the dominant. Despite the presence of a similar mosses community as in the previous habitat the local community of cyanobacteria was very different. The dominance of Lyngbya aestuarii results from special habitat conditions in the area. It is a seaside habitat, under the influence of sea spray. Distinctive habitat conditions shaped its dominance and the species was accompanied by Geitlerinema acutissimum (sub-dominant), Leptolyngbya valderiana, small cells
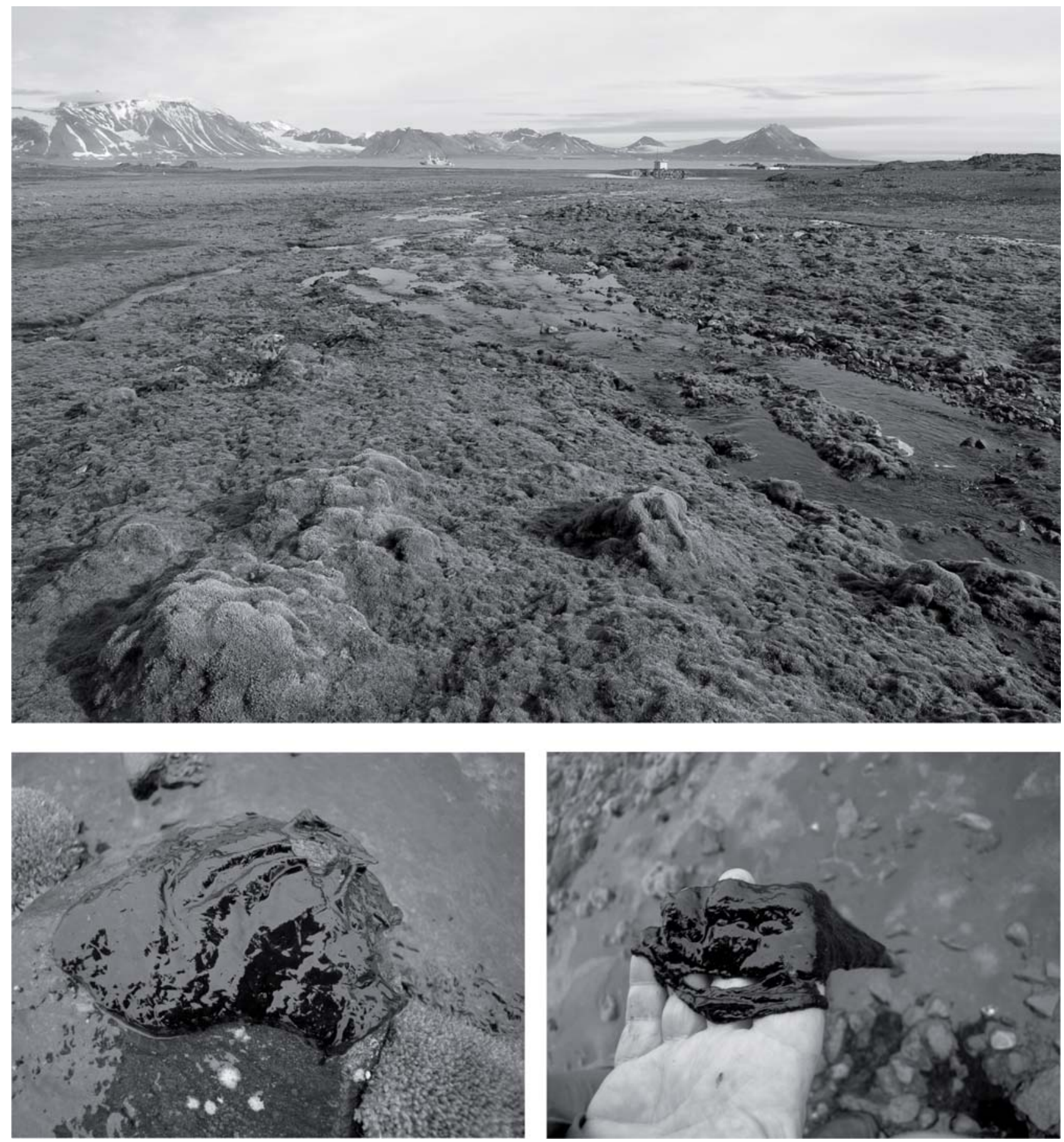

Figure 5. View of the mesotrophic habitat with flowing water and macroscopic Phormidium autumnale mats (MF) 
of Woronichinia sp. In uncovered locations on the soil the study also recorded patches of Nostoc commune thalli.

In oligotrophic wet moss habitat (WM), (Fig. 6) covered by a mosaic of mosses (Saxifraga oppositifolia, Sanionia uncinata, Aulacomnium palustre, Pohlia nutans) on the soil surface, between the mosses the dominant was Nostoc punciforme and N. cf. palludosum (subdominant), creating clearly visible, black or dark blue spherical thallus. Among them there were Gloeothece cf. incerta.

Mesotrophic wet moss habitat (MM), (Fig. 6) was covered by Saxifraga oppositifolia and Deschampsia borealis with Plagomnium ellipticum, Pohlia nutans. Between bare patches of soil and between the mosses Microcoleus autumnalis was the dominant species, creating large spread thallus. Among the filaments there were also the thalli of Pseudanabaena frigida, Phormidium uncinatum, Woronichinia compacta, Merismopedia sp. There was also a small share thalli of $N$. cf. punctiforme.

Mesotrophic habitat with flowing water (MF), (Fig. 5) was also characterized by the dominance of Microcoleus autumnalis (forming mats), whose proportion in the community was between 40 and $60 \%$. It occurred as dark brown, thin thalli on mosses, rocks and wet soil. Between the leaves of mosses there were also lobular thalli of the thin form of Leptolyngbya sp. The species distinctive for this tundra was Schizothrix cf. facilis occurring as long filaments in the water and at the bottom of streams. A lot of species of non-heterocytous types of cyanobacteria (Geitlerinema acutissimum, Pseudanabaena catenata, Leptolyngbya valderiana, Oscillatoria fracta) were also noted.

\section{Discussion}

Studies conducted over several years in the Hornsund area allowed us to distinguish several types habitats characterized by particular kinds of mosses, vascular plants and phycoflora (Richter et al., 2014b; Richter et al., 2015). In each of the analyzed habitats cyanobacteria had an important role, especially in initial habitats. They occupied vast surfaces of the analyzed area and were often essential in the production of biomass.

During research in oligotrophic habitats it was noted that uncovered soil was visibly dominated by cyanobacterial crusts, and by Nostoc commune thalli. In these difficult

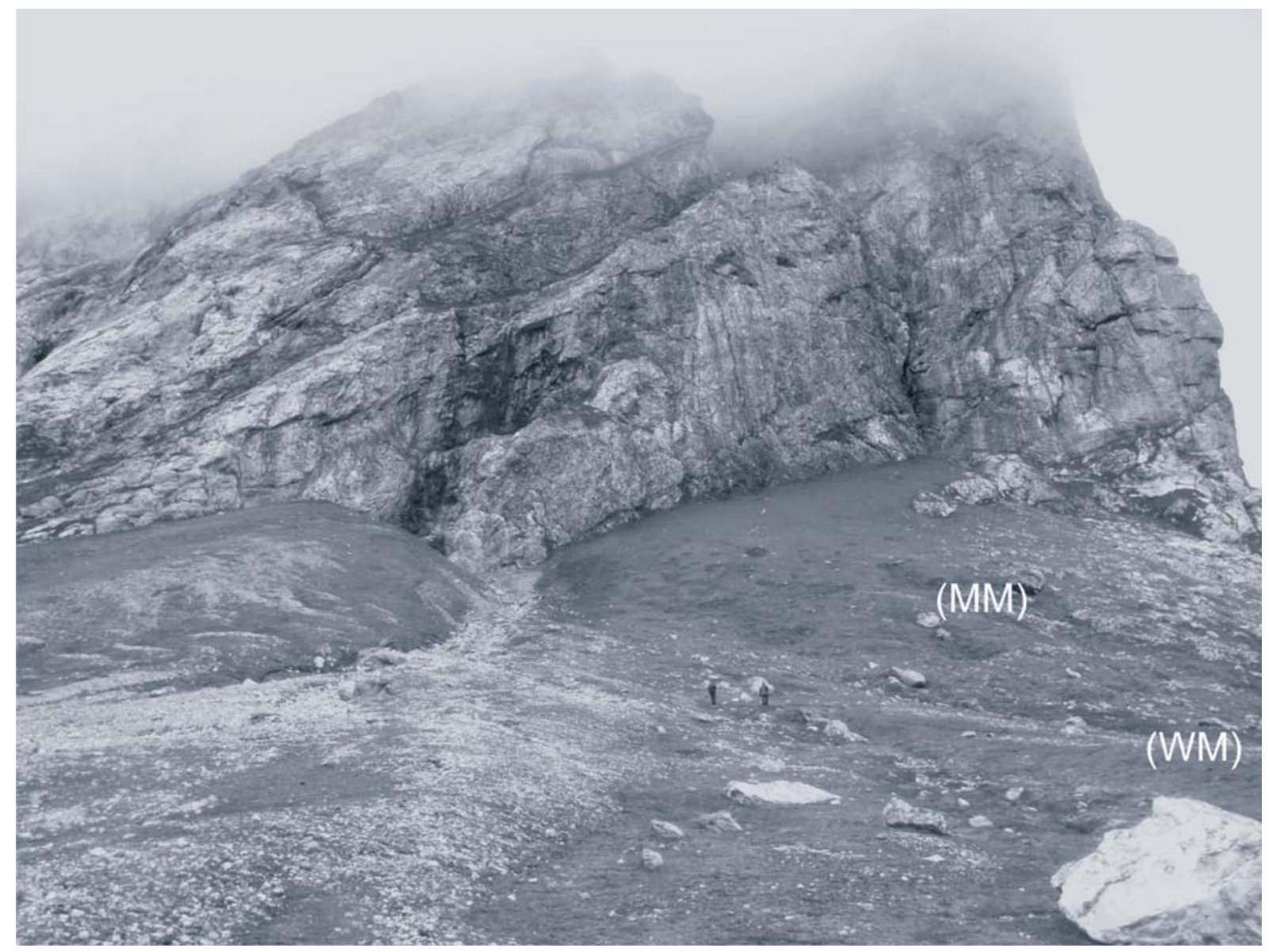

Figure 6. View of the Gnalberget slope 
conditions the colonization success of cyanobacteria assemblages in the form of crusts results from their accommodation to environmental stresses, such as drastic fluctuations in temperature and drying and radiation (Oleksowicz \& Luścińska, 1992; Hu et al., 2012; Komárek \& Kovacik, 2013).

In the majority of the studied oligotrophic habitats in the Hornsund region cyanobacteria crusts are formed by Schizotrix cf. lacustris and the accompanying species such as Microcoleus vaginatus, Tolypothrix tenuis, Scytonema crustaceum and species of the genera Gloeocapsa, Chroococcus. This results from the fact that filamentous sheath-forming species (e.g. Schizothrix, Microcoleus) are best adapted to the tundra conditions because the presence of a sheath and mucilage can help protect cells against physical desiccation (Friedmann et al., 1988; Mazor et al., 1996; Gupta \& Agrawal, 2008). In habitats of this type, in mosses communities, Sanionia uncinata has always been present in mosaic with other mosses, such as Bryum sp. or Sanionia uncinata is one of the dominating species of mosses in the Arctic because it is adapted to extreme conditions. The dominance of mosses in the region derives from the fact that many of them are able to use nitrogen due to high activity of epiphytic cyanobacteria cooperating with them. The research by Karagatzides et al. (1985) and Solheim et al. (1996) describe Sanionia sp. and Bryum sp. as the most popular host plants for cyanobacteria.

During the Hornsund research conducted in low nutrient oligotrophic habitats it was observed that there is a connection between the presence of Sanonia uncinata and the occurrence of heterocytous cyanobacteria. It was particularly visible in case of Nostoc commune and Nostoc cf. punctiforme. In polar regions habitats low in nutrients have a big share of heterocytous species (Matuła et al., 2007; Richter et al., 2009; Komárek \& Elster, 2008; Komárek \& Komárek, 2010; Richter et al., 2014b, 2015). The accompanying vegetation, mostly bryophytes, often forms strict associations with cyanobacteria. These may include Anabaena and Calothrix sp., but most often the genus Nostoc (Nakatsubo \& Ino, 1986, 1987), which is the most commonly spread species from the Antarctic, especially in surface habitats, where it may reach macroscopic sizes (Vincent et al., 1986; Fumanti et al., 1995; Cavacini, 2001; Hirai et al., 2004; Fukunda et al., 2008; Komárek \& Elster, 2008; Komárek \& Komárek, 2010). The dominance of Nostoc commune thalli was also observed in oligotrophic habitats, where Bryum pseudotriquetrum was recorded. Othani's research (1986) confirmed this and proved that Nostoc commune often occurs in leaves and branches of the moss, forming an association.

Another interdependency was observed in habitats with Paludella squarosa dominance. Covering the habitats under sea spray Paludella squarosa co-created a community with a dominance of cyanobacterial mats with Geitlerine- ma acutissimum and Lyngbya aestuarii. This resulted from the particular habitat conditions in the coastal area. Lyngbya aestuarii is a species with a large spectrum of occurrence in salty environments (Silva et al., 1996; Galil et al., 2011; Kothari et al., 2013). On the other hand, in the conditions of an oligotrophic habitat Paludella squarrosa was characteristic of habitats on lime soils (Dierssen, 2001), which was reflected in the presence of blue green algae. Cyanobacterial crusts were formed of Schizothrix cf. calcicola and Dichothrix gypsophila, species, whose sheaths are richly incrusted with calcium carbonate (Komárek \& Anagnostidis, 2005; Komárek, 2013).

Mesotrophic habitats are characterized by unusually rich bryophyte vegetation, vascular vegetation (Saxifraga oppositifolia, Tetraplodon mnioides, Straminergon stramineum) and phycoflora richness. Cyanobacterial crusts and mats are of lesser importance. Filamentous cyanobacteria are present, non-heterocytous of the Oscillatoria, Pseudanabaena, Phormidium genera Microcoleus autumnalis is observed in mesotrophic habitats in Hornsund forming dark brown, flat wide-spread mats attached to mosses, rock and ground, and constituting as much as $70 \%$ of cyanobacterial and algal community. In polar regions Microcoleus autumnalis is characteristic of humid subaerophytic habitats (Vincent, 2000; Komárek \& Elster, 2008; Strunecký et al., 2013). The analyzed habitats also had numerous occurrences of Pseudanabaena frigida. It has a broad spectrum occurrence in relation to trophy and surface (Fumanti et al., 1995, 1997; Matuła et al., 2007; Richter et al., 2009; Davydov, 2014), but occurs most often in mesotrophic moss tundra.

The large share of cyanobacteria in the habitats structure confirms their important role in creating the mosaic communities of Arctic tundra. The conducted research indicates correlation between the occurrence of particular cyanobacteria species and mosses or vascular plants in habitats diverse in trophy and moisture.

\section{Conclusions}

The paper is concerned with the relations between cyanobacterial assemblages and vegetation in Arctic ecosystems. The studies were conducted in the area of Hornsund fjord in 14 types of habitats diversified in humidity and trophy. In the habitats, qualitative and quantitative analyses of phycoflora were conducted along with floristic analyses of mosses and vascular plants. The study distinguished plant assemblages and cyanobacterial assemblages forming cyanobacterial thalli and crusts characteristic of particular habitats. As a result, the habitats were grouped into 10 categories with a specific combinations of species and clear relations between cyanobacteria and mosses or vascular plants. The observed relations between cyanobacterial as- 
semblages and vegetation and the often dominating role of cyanobacteria in Arctic ecosystems indicate their significant role in the formation of the Arctic ecosystem and suggest they should be included in the descriptions of communities present in the region.

\section{References}

Cavacini P., 2001, Soil algae from northern Victoria Land (Antarctica). Pol. Biosci. 14: 45-60.

Chapin D.M., Bledsoe C.S., 1992, Nitrogen fixation in arctic plant communities, [in:] F. Chaplin., R. Jefferies, J.F. Reynolds, G.R. Shaver, J. Svoboda (eds). Arctic ecosystems in a changing climate: An Ecophysiological Perspective. Academic Press, San Diego: 301-319.

Cooper E.J., Alsos I.G., Hagen D, Smith F.M., Coulson S.J. \& Hodkinson I.D., 2004, Plant recruitment in the High Arctic: seed bank and seedling emergence on Svalbard. Journal of Vegetation Science 15: 115-124.

Cooper E.J., 2011, Polar desert vegetation and plant recruitment in Murchisonfjord, Nordaustlandet, Svalbard. Geografiska Annaler, Series A, 93: 243-252.

Davydov D., 2013, Cyanoprokaryota in polar deserts of Rijpfjorden east coast, North-East Land (Nordaustlandet) Island, Spitsbergen. Algological Studies 142: $29-44$.

Davydov D., 2014, Diversity of the Cyanoprokaryota of the area of settlement Pyramiden, West Spitsbergen Island, Spitsbergen archipelago. Folia Cryptogamica Estonica 51: 13-23.

Davydov D., 2016, Diversity of the Cyanoprokaryota in polar deserts of Innvika cove North-East Land (Nordaustlandet) Island, Spitsbergen. Czech Polar Reports 6: 66-79.

Davydov D., 2017, Cyanoprokaryotes of the west part of Oscar II Land, West Spitsbergen Island, Spitsbergen archipelago. Czech Polar Reports 7(1): 94-108.

Davydov D. \& Patova E., 2017, The diversity of Cyanoprokaryota from freshwater and terrestrial habitats in the Eurasian Arctic and Hypoarctic. Hydrobiologia P.1-19. (https://doi.org/10.1007/s10750-017-3400-3).

Dickson L.G., 2000, Constraints to nitrogen fixation by cryptogamic crusts in a polar desert ecosystem, Devon Island, N. W. T., Canada. Arct. Alp. Res. 32: 40-45.

Dierssen K., 2001, Distribution, ecological amplitude and phytosociological characterization of European bryophytes. J. Cramer Publisching Company, Stuttgart.

Dubiel E. \& Olech M., 1990, Plant communities of NW Sørkapp Land (Spitsbergen). Zesz. Nauk. Uniw. Jagiellon., Prace Botaniczne 21: 35-74.

Elster J. \& Benson E., 2004, Life in the Polar Terrestrial Environment: a Focus on Algae and Cyanobacteria, [in:] B. Fuller, N. Lane,
E.E. Benson (eds), Life in the frozen state. Taylor and Francis, London: 111-149.

Elvebakk A., 1994, A survey of plant associations and alliances from Svalbard. Journal of Vegetation Science 5 (6): 757-924.

Elvebakk A., 2005, A vegetation map of Svalbard on the scale 1:3.5 mill. Phytocoenologia 35 (4): 951-967.

Friedmann E.I., Hua M. \& Ocampo-Friedmann R., 1988, Cryptoendolithic lichen and cyanobacterial communities of the Ross Desert, Antarctica. Polarforschung 58: 251-259.

Fukunda S., Yamakawa R., Hirai M., Kasino Y.K.H. \& Satoh K., 2008, Mechanisms to avoid photoinhibition in a desiccation-tolerant cyanobacterium Nostoc commune. Plant Cell Physiol. 49 (3): 488-492.

Fumanti B., Alfinito S. \& Cavacini P., 1995, Floristic studies on freshwater algae of Lake Gondwana, northern Victoria Land (Antarctica). Hydrobiol. 316: 81-90.

Fumanti B., Cavacini P. \& Alfinito S., 1997, Benthic algal mats of some lakes of Inexpressible Island (northern Victoria Land, Antarctica). Polar Biol. 17: 25-30.

Galil B., Goren M. \& Mienis H., 2011, Checklist of marine species in Israel. Compiled in the framework of the EU FP7 PESI project. (http://www.marinespecies.org/aphia.php? $p=$ source de - tails \&id=149096).

Gavazov K.S, Soudzilovskaia N.A., van Logtestijn R., Braster M. \& Cornelissen J., 2010, Isotopic analysis of cyanobacterial nitrogen fixation associated with subarctic lichen and bryophyte species. Plant Soil. 333: 507-517.

Gupta S. \& Agrawal S.C., 2008, Vegetative survival of some wall and soil blue-green algae under stress conditions. Folia Microbiologica 53(4): 343-350.

Hirai M., Yamakawa R., Nishio J., Yamaji T., Kashino Y., Koike H. \& Sath K., 2004, Deactivation of photosynthetic activities is triggered by loss of a small amount of water in a desiccation-tolerant cyanobacterium, Nostoc commune. Plant Cell Physiol. 45(7): 872-878.

Hu Ch. X. \& Liu Y.D., 2003, Primary succession of algal community structure in desert soil. Acta Botanica Sinica 45 (8): 917-924.

Hu Ch.X., Gao K. \& Whitton B.A., 2012, Semi-arid Regions and Deserts, [in:] B.A Whitton (ed.), Ecology of Cyanobacteria II. Springer, New York: 345-347.

Kanda H. \& Inoue M., 1994, Ecological monitoring of moss and lichen vegetation in the Syowa Station Area, Antarctica. Proc. NIPR Symp. Polar Biol. 7: 221-231.

Karagatzides J.D., Lewis M.C. \& Schulman H.M., 1985, Nitrogen fixation in the high arctic tundra at Sarcpa Lake, Northwest Territories. Canadian Journal of Botany 63 (5): 974-979.

Kaštovská K., Elster J., Stibal M. \& Šantrůčková H., 2005, Microbial assemblages in soil microbial succession af- 
ter glacial retreat in Svalbard (High Arctic). Microbiol. Ecol. 50: 396-407.

Kim G.H., Klockova T.A., Han J.W. \& Kang S.-H., 2008, Notes on freshwater and terrestrial algae Ny-Ålesund, Svalbard (High Arctic sea area). Journal of Environmental Biology 29: 485-491.

Kim G.H., Klockova T.A. \& Kang S-H., 2011, Freshwater and terrestrial algae from $\mathrm{Ny}-\AA$ Alesund and Blomstrandhalvøya Island (Svalbard). Arctic 64(1): 25-31.

Komárek J. \& Anagnostidis K., 1999, Cyanoprokaryota; Chroococcales, [in:] H. Ettl, G. Gärtner, H. Heyning, D. Mollenhauer (eds), Süsswasserflora von Mitteleuropa. Spektrum Akademischer Verlag, Heidelberg, Berlin.

Komárek J. \& Anagnostidis K., 2005, Cyanoprokaryota; Oscillatoriales II, [in:] B. Büdel, G. Gärtner, L. Krientz, M. Schager (eds), Süsswasserflora von Mitteleuropa. Spektrum Akademischer Verlag, Müchen.

Komárek J. \& Elster J., 2008, Ecological background of cyanobacterial assemblages of the northern part of James Ross Island, NW Weddell Sea, Antarctica. Pol. Polar Res. 29 (1): 17-32.

Komárek O. \& Komárek J., 2010, Diversity and ecology of cyanobacterial microflora of the seepages habitat. Comparison of King George Island, Shetland Islands, and James Ross Island, NW Weddell Sea, Antarctica, [in:] J. Seckbach (ed.), Microbial Mats. Springer Verlag, Dodrecht: 517-539.

Komárek J., Kovacik L., Elster J. \& Komárek O., 2012, Cyanobacterial diversity of Petunia-Bukta, Billefjorden, central Svalbard. Pol. Polar Res. 33: 347-368.

Komárek J. \& Kovacik L., 2013, Schizotrichacean cyanobacteria from central Spitsbergen (Svalbard). Polar Biol. 36: 1811-1822.

Komárek J., 2013, Cyanoprokaryota; Heterocytous Genera III, [in:] B. Büdel, G. Gärtner, L. Krientz, M. Schager (eds), Süsswasserflora von Mitteleuropa. Springer Spectrums, Berlin Heidelberg.

Kothari A., Vaughn M. \& Garcia-Pichel F., 2013, Comparative genomic analyses of the cyanobacterium, Lyngbya aestuarii BL J, a powerful hydrogen producer. Front. Microbiology 4: 363.

Kvíderová J., Elster J. \& Šimek M., 2011, In situ response of Nostoc commune s.1. colonies to desiccation, in Central Svalbard, Norwegian High Arctic. Fottea 11(1): 87-97

Lindo Z., Nilsson M.-Ch. \& Gundale M.J., 2013, Bryophyte-cyanobacteria associations as regulators of the northern latitude carbon balance in response to global change. Global Change Biology 19(7): 2022-2035.

Matuła J., 1982, Investigations on the algal flora of West Spitsbergen. Acta Uni. Wratis. 525: 173-194.

Matuła J., Pietryka M., Richter D. \& Wojtuń B., 2007, Cyanobacteria and algae of Arctic terrestrial ecosystems in the Hornsund area, Spitsbergen. Pol. Polar Res. 28: 283-315.

Mazor G., Kidron G.J., Vonshak A. \& Abeliovich A., 1996, The role of cyanobacterial exopolysaccharides in structuring desert microbial crusts. Microbiol. Ecol. 21(2): 121-130

Nakatsubo T. \& Ino Y., 1986, Nitrogen cycling in an Antarctic ecosystem. 1. Biological nitrogen fixation in the vicinity of Syowa Station, Memoirs of National Institute of Polar Research 37: 1-10.

Nakatsubo T. \& Ino Y., 1987, Nitrogen cycling in an Antarctic ecosystem. 2. Estimation of the amount of nitrogen fixation in a moss community on East Ongul Island. Ecological Research 2(1): 31-40.

Olech M., 1990, Preliminary studies on ornithocoprophilous lichens of the Arctic and Antarctic regions. Polar Biol. 3: 218-223.

Olech M., 2008, Kolonizacja i sukcesja roślinności na przedpolach lodowców w Antarktyce Zachodniej [Plant colonization and succession on the Glacier forefi elds in West Antarctica], A. Kowalska (ed.), The 32nd International Polar Symposium, 4th International Polar Year, 23-24 May 2008, Skrypt XXXII, Wrocław: 59-60.

Oleksowicz A. \& Luścińska M., 1992, Occurrence of algae on tundra soils in Oscar II Land, Spitsbergen. Pol. Polar Res. 13(2): 131-147.

Ohtani S., 1986, Epiphytic algae on mosses in the vicinity of Syowa Station, Antarctica, Memoirs of National Institute of Polar Research, Special issue 44: 209-219.

Plichta W. \& Luścińska M., 1988, Blue-green algae and their influence on development of tundra soils in Kaffiöyra, Oscar II Land, Spitsbergen. Polish Polar Research 9: 475-484.

Pócs T., 2009, Cyanobacterial crust types, as strategies for survival in extreme habitats. Acta Bot. Hun. 51(1-2): 147-178.

Raabová L., Elster J. \& Kováčik L., 2016, Phototrophic microflora colonizing substrates of man-made origin in Billefjorden Region, Central Svalbard. Czech Polar Reports 6: 21-30.

Rai A.N., Söderbäck E. \& Bergman B., 2000, Tansley review no. 116 cyanobacterium - plant symbioses. The New Phytologist 147(3): 449-481.

Richter D., Matuła J. \& Pietryka M., 2009, Cyanobacteria and algae of selected habitats in tundra around Hornsund fiord (West Spitsbergen). Oceanol. and Hydrobiol. Studies 38: 1-6.

Richter D. \& Matuła J., 2013, Leptolyngbya sieminskae sp. n. (Cyanobacteria) from Svalbard. Pol. Polar Res. 34(2): 151-168.

Richter D., Matuła J. \& Pietryka M., 2014a, The northernmost populations of Tetraspora gelatinosa (Chloro- 
phyta) from Spitsbergen. Pol. Polar Res. 35 (3): 521 538.

Richter D., Pietryka M. \& Matuła J., 2014b, The diversity of cyanobacteria and green algae on ecological different types of vegetation in Horsund area (West Spitsbergen, Svalbard), [in:] K. Migała, P. Owczarek, M. Kasprzak, M. Strzelecki (eds), New perspectives in polar research. University of Wrocław, Wrocław: 139-164.

Richter D., Pietryka M. \& Matuła J., 2015, Relationship of cyanobacteral and algal assemblages with vegetation in the high Arctic tundra (West Spitsbergen, Svalbard Archipelago). Pol. Polar Res. 36(3): 137-162.

Rousk K., Jones D.L. \& De Luca T.H., 2013, Moss-cyanobacteria associations as biogenic sources of nitrogen in boreal forest ecosystems. Front. Microbiol. 4: 150.

Silva P.C., Basson P.W. \& Moe R.L., 1996, Catalogue of the benthic marine algae of the Indian Ocean. Univ. of California Press, Berkeley.

Skulberg O.M., 1996, Terrestrial and limnic algae and cyanobacteria, [in:] A. Elvebakk, P. Prestrud (eds), A catalogue of Svalbard plants, fungi, algae and cyanobacteria. Norsk Polarinstitutt, Skrifer, Oslo: 383-395.

Solheim B., Endal A. \& Vigstad H., 1996, Nitrogen fixation in Arctic vegetation and soils from Svalbard, Norway. Polar Biol. 16: 35-40.

Solheim B. \& Zielke M., 2002, Associations between cyanobacteria and mosses, [in:] A.N. Rai, B. Bergman, U. Rasmussen (eds), Cyanobacteria in Symbiosis. Kluwer Academic Publishers, Stockholm, Sweden: 137152.

Steinberg N. \& Meeks J., 1991, Physiological sources of reductant for nitrogen fixation activity in Nostoc sp. strain UCD 7801 in symbiotic association with Anthoceros punctatus. J. Bacteriol. 173(22): 7324-7329.

Stewart K., Lamb E., Coxson D. \& Sicilian S., 2011, Bryophyte-cyanobacterial associations as a key factor in N2-fixation across the Canadian Arctic. Plant and Soil 344: 335-346.

Strunecký O., Komárek J. \& Elster J., 2012, Biogeography of Phormidium autumnale (Oscillatoriales, Cyanobacteria) in western and central Spitsbergen. Pol. Polar Res. 33 (4): 369-382.

Strunecký O., Komárek J., Johansen J., Lukešová A. \& Elster J, 2013, Molecular and morphological criteria for revision of the genus Microcoleus (Oscillatoriales, Cyanobacteria). J. Phycol. 49: 1167-1180.

Thomas D.N., Fogg G.E., Konvey P., Fritsen C.H., Gili M., Gradinger R., Laybourn-Pary J., Reid K. \& Walton D.W.H., 2008, The Biology of Polar Regions. Oxford University Press, Oxford, UK.

Thomasson K., 1958, Zur planktonkunde Spitzbergens, 1. Hydrobiologia 12: 226-236.

Thomasson K., 1961, Zur planktonkunde Spitzbergens, 2. Hydrobiologia 18: 192-198.

Turicchia S., Ventura S., Schütte U., Soldati E., Zielke M. \& Solheim B., 2005, Biodiversity of the cyanobacterial community in the foreland of the retreating glacier Midtre Lovènbreen, Spitsbergen, Svalbard. Algological Studies 117: 427-440.

Turetsky M.R., 2003, The role of bryophytes in carbon and nitrogen cycling. The Bryologist 106(3): 395-409.

Turetsky M.R., Bond-Lamberty B., Euskirchen E., Talbot J., Frolking S., McGuire A.D. \& Tuittila E.S., 2012, The resilience and functional role of moss in boreal and arctic ecosystems. New Phytol. 196 (1): 49-67.

Vincent W.F. \& Howard-Williams C., 1986, Antarctic stream ecosystems: physiological ecology of a bluegreen algal epilithon. Freshwater Biology 16(2): 219233.

Vincent W.F., 2000, Cyanobacterial dominance in the Polar Regions, [in:] B.A. Whitton, M. Potts (eds), The Ecology of Cyanobacteria. Kluwer Academic Publishers, Dordrecht: $321-340$.

Warwick F.V., 2002, Cyanobacterial dominance in the Polar Regions, [in:] The Ecology of Cyanobacteria, B.A. Whitton, M. Potts (eds). Springer, Netherlands: 231-340.

Willen T., 1980, Phytoplankton from Lakes and Ponds on Vestspitsbergen. Acta Phytogeographica Suecica 68: 173-188.

Zhang X., Feng J., Wang G. \& Xie S., 2014, A morphological and phylogenetic study of a filamentous cyanobacterium, Microcoleus vaginatus, associated with the moss Mnium cuspidatum. Symb. 64: 43-51.

Zielke M., Solheim B., Spjelkovik S. \& Olsen R.A., 2002, Nitrogen fixation in the High Arctic: role of vegetation and environmental conditions. Arct. Antarct. Alp. Res. 37(3): 372-378. 